\title{
HUBUNGAN SIKAP KERJA, PENCAHAYAAN DAN SUHU TERHADAP KELELAHAN KERJA DAN KELELAHAN MATA PADA PENJAHIT DI KAMPUNG SOLOR KUPANG 2017
}

\section{The Relationship Between Work Attitude, Lighting, And Temperature Towards Work Fatigue and Eye Fatigue at Tailors in Kampung Solor Kupang 2017}

\author{
${ }^{1}$ Kristina Dede Odi, ${ }^{2}$ Sintha Lisa Purimahua, ${ }^{3}$ Luh Putu Ruliati \\ ${ }^{1}$ Alumni Bagian Kesehatan Lingkungan dan Kesehatan Kerja - Prodi IKM, FKM UNDANA \\ ${ }^{23}$ Dosen Bagian Kesehatan Lingkungan dan Kesehatan Kerja - Prodi IKM, FKM UNDANA
}

\begin{abstract}
The discomfort of work environment which is caused by temperature will affect a worker to complete his or her job. For lack of attention to work place adjusment, position, and work equipment will certanly cause problems dealing with occupational desease. Job that have a need of accuracy without unequal to lighting, have the impact to eye fatigue. This study was aimed to find out the relationship of attitude to work, lighting, and temperature towards work fatigue and eye fatigue at tailors in Kampung Solor Kupang 2017. The type of this research was an analytic survey with cross sectional approach. The number of population was 34 tailors with the total sample 34 tailors who spread in 16 of stitch. In analising the data, the researcher used chi square with significant correlation to work fatigue, $p$ value $=0,011$. Work attitude had significant correlation to eye fatigue with $p$ value $=0,037$, lighting had no significant correlation to work fatigue with $p$ value $=0,683$, lighting had correlation with eye fatigue $p$ value $=0,045$, temperature had significant relation to work fatigue by $p$ value $=0,023$ and it had no correlation to eye fatigue by $p$ value $=0,106$.
\end{abstract}

Keywords : Work Attitude, Lighting, Temperature, Work Fatigue, Eye Fatigue, Tailor.

\begin{abstract}
Abstrak
Ketidaknyamanan lingkungan kerja yang disebabkan oleh suhu akan mempengaruhi pekerja untuk menyelesaikan pekerjaannya. Karena kurangnya perhatian terhadap penempatan tempat kerja, posisi, dan peralatan kerja akan menyebabkan masalah dalam penanganan pekerjaan. Pekerjaan yang memiliki kebutuhan akurasi tanpa ketidaksetaraan terhadap pencahayaan, berdampak pada kelelahan mata. Penelitian ini bertujuan untuk mengetahui hubungan sikap terhadap pekerjaan, pencahayaan, dan suhu terhadap kelelahan kerja dan kelelahan mata pada penjahit di Kampung Solor Kupang 2017. Jenis penelitian ini adalah survei analitik dengan pendekatan cross sectional. Jumlah populasi adalah 34 penjahit dengan total 34 sampel yang tersebar di 16 jahitan. Dalam menganalisa data, peneliti menggunakan chi square dengan korelasi yang signifikan terhadap kelelahan kerja, $p$ value $=0,011$. Sikap kerja memiliki hubungan yang signifikan terhadap kelelahan mata dengan $p$ value $=0,037$, pencahayaan tidak memiliki korelasi yang signifikan terhadap kelelahan kerja dengan nilai $p=0,683$, pencahayaan berkorelasi dengan nilai $\mathrm{p}$ kelelahan mata $=0,045$, suhu memiliki hubungan yang signifikan terhadap kelelahan kerja dengan $\mathrm{p}$ value $=0,023$ dan tidak ada korelasi dengan kelelahan mata dengan nilai $\mathrm{p}=0,106$.
\end{abstract}

Kata kunci: Sikap Kerja, Pencahayaan, Suhu, Kelelahan Kerja, Kelelahan Mata, Penjahit.

1 Kristina Dede Odi adalah Alumni Bagian Kesehatan Lingkungan dan Kesehatan Kerja Program Studi IKM FKM UNDANA

23 Sintha Lisa Purimahua dan Luh Putu Ruliati adalah Dosen Bagian Kesehatan Lingkungan dan Kesehatan Kerja Program Studi IKM FKM UNDANA 


\section{PENDAHULUAN}

Dalam upaya mendukung perekonomian Kota Kupang, pemerintah menyediakan kawasan-kawasan industri dengan manajemen terpadu. Kebijakan pengembangan sektor industri juga mencakup kebijakan pengembangan subsektor Usaha Kecil Menengah (UKM). Tersedianya kawasan perindustrian ini maka dituntut kemampuan sumber daya manusia yang berkualitas dan memiliki kondisi kesehatan yang prima untuk meningkatkan produktivitas kerja guna memperoleh keluaran yang maksimal, sehingga mampu bersaing dalam menghasilkan barang dan jasa yang bermutu tinggi. Namun, menurut Notoatmodjo (2003) bahwa umumnya usaha sektor informal belum memperhatikan dengan serius masalah yang berkenaan dengan ergonomi, mulai dari posisi kerja, peralatan kerja dan penyesuaian antara peralatan kerja dengan kondisi tenaga kerja yang menggunakan peralatan. Dengan kurangnya perhatian akan penyesuaian tempat kerja, posisi, serta peralatan terhadap tenaga kerja, tentunya akan menimbulkan beberapa permasalahan berupa penyakit akibat kerja.

Penerangan merupakan salah satu faktor fisik yang ada di tempat kerja, penerangan yang buruk dapat mengakibatkan kelelahan mata dengan berkurangnya daya efisiensi kerja, kelelahan mental, keluhan-keluhan pegal di daerah mata dan sakit kepala di sekitar mata, kerusakan alat penglihatan dan meningkatkan kecelakaan kerja (Suma'mur, 2009). Penerangan yang baik adalah penerangan yang memungkinkan tenaga kerja dapat melihat objek yang dikerjakannya secara jelas, cepat dan tanpa upaya-upaya yang tidak perlu (Suma'mur, 2009). Fungsi utama pencahayaan di tempat kerja adalah untuk menerangi obyek pekerjaan agar terlihat jelas, mudah dan dikerjakan dengan cepat dan produktivitas dapat meningkat. Pencahayaan yang intensitasnya rendah akan menimbulkan kelelahan, ketegangan mata, dan keluhan pegal disekitar mata (Santoso, 2004). Sesuai dengan Keputusan Menteri Kesehatan RI No 1405/MENKES/SK/XI/2002 tentang Persyaratan Lingkungan Kerja Industri, intensitas minimal untuk pekerjaan rutin dengan menggunakan mesin seperti menjahit adalah 300-500 lux.

Ketidaknyaman lingkungan kerja yang disebabkan oleh temperatur juga akan mempengaruhi penyelesaian pekerjaan dari seorang pekerja. Panas yang berlebihan di tubuh baik akibat proses metabolisme tubuh maupun paparan panas dari lingkungan kerja dapat menimbulkan masalah kesehatan. Menurut Grandjean (1986) dalam Nurmianto (2003) kondisi panas sekeliling yang berlebihan akan mengakibatkan rasa lelah dan kantuk, mengurangi kestabilan dan meningkatnya jumlah angka kesalahan kerja. Menurut Keputusan Menteri Kesehatan Republik Indonesia Nomor 1405/MENKES/SK/XI/2002 Persyaratan kesehatan untuk ruang kerja industri yang nyaman di tempat kerja adalah suhu yang tidak dingin dan tidak menimbulkan kepanasan bagi tenaga kerja yaitu berkisar antara $18-30^{\circ} \mathrm{C}$ dengan tinggi langit-langit dari lantai minimal 2,5 m.

Kelelahan merupakan kondisi melemahnya tenaga untuk melakukan suatu kegiatan yang biasa terjadi kepada semua orang dalam kehidupan seharihari dan disertai penurunan efisiensi dan kebutuhan dalam bekerja (Budiono, dkk, 2003, sedarmayanti, 2009). Kelelahan kerja adalah suatu pola yang timbul pada suatu keadaan yang secara umum terjadi 
pada pekerja, dimana pekerja tidak sanggup lagi untuk melakukan pekerjaan sehingga mengakibatkan terjadinya penurunan produktivitas kerja akibat faktor pekerjaan (Riyadi, 1996, Sedarmayati, 2009). Kelelahan dibagi atas dua jenis, yaitu kelelahan otot merupakan tremor pada otot atau perasaan nyeri pada otot dan kelelahan umum merupakan kelelahan yang ditandai dengan berkurangnya kemauan untuk bekerja yang disebabkan oleh pekerjaan yang sifatnya statis atau monoton, intensitas dan lamanya kerja fisik, keadaan lingkungan, kondisi mental dan psikologis, status kesehatan dan gizi (Budiono, dkk, 2003).

$$
\text { Kelelahan mata adalah }
$$

ketegangan pada mata dan disebabkan oleh penggunaan indera penglihatan dalam bekerja yang memerlukan kemampuan untuk melihat dalam jangka waktu yang lama dan biasanya disertai dengan kondisi pandangan yang tidak nyaman. Kelelahan mata timbul sebagai stress intensif pada fungsi-fungsi mata seperti terhadap otot-otot akomodasi pada pekerjaan yang perlu pengamatan secara teliti atau terhadap retina akibat ketidaktepatan kontras (Suma'mur, 2009). Pada pekerjaan yang memerlukan ketelitian tanpa penerangan yang memadai, maka dampaknya akan sangat terasa pada kelelahan mata. Terjadinya kelelahan otot mata dan kelelahan syaraf mata sebagai akibat tegang yang terus menerus pada mata, walaupun tidak menyebabkan kerusakan secara permanen, tetapi menambah beban kerja, mempercepat lelah, sering istirahat, kehilangan jam kerja dan mengurangi kepuasan kerja, penurunan mutu produksi, meningkatkan frekuensi kesalahan, mengganggu konsentrasi dan menurunkan produktivitas kerja (Manuaba, 1992).
Berdasarkan survei pendahuluan yang dilakukan di usaha informal tempat jahit di Kampung Solor terdapat 16 tempat jahit, dengan jumlah penjahit sebanyak 34 orang. Pekerjaan dimulai dari pukul 08-30-18.00 WITA dengan istirahat selama 1 jam yaitu pada pukul 12.00-13.00 WITA. Hasil wawancara ditemukan bahwa gangguan kesehatan yang dialami pekerja khusus tahap menjahit potongan kain berupa keluhan nyeri pada leher, punggung, pinggang, dan betis. Berdasarkan pengamatan dan pengukuran yang dilakukan, di 16 tempat usaha jahit menggunakan pencahayaan alami dan pencahayaan buatan. Dari 16 tempat usaha jahit ada 8 tempat usaha jahit yang melebihi standar dengan intensitas penerangan yaitu : 512-966 lux dan 2 tempat usaha jahit yang di bawah standar dengan intensitas penerangan yaitu 272-288 lux bila dibandingkan dengan standar yang ditetapkan maka intensitas pencahayaan di tempat jahit tersebut tidak memenuhi syarat, secara teori kondisi ini dapat menyebabkan kelelahan mata pada tenaga penjahit. Dari 16 tempat jahit 15 diantaranya bersuhu $33^{\circ} \mathrm{C}$ hal ini di sebabkan kurang tersedianya ventilasi sehingga menyebabkan kurangnya sirkulasi udara, tinggi lantai dengan langit-langit $\quad 2,0 \quad \mathrm{~m}$. Berdasarkan wawancara terhadap 34 orang penjahit, didapatkan bahwa tiap harinya penjahit dapat menghasilkan \pm 3 potong pakaian dan mengeluhkan kelelahan otot seperti pegal pada bagian pinggang dan lelah pada mata, kelelahan umum seperti menurunnya gairah kerja dan cepat merasa jenuh saat bekerja dan setelah bekerja yang disebabkan oleh lamanya jam kerja atau hari yaitu $>8$ jam kerja dan faktor pencahayaan, suhu yang dirasa panas dan beban kerja dilingkungan kerja. Berdasarkan wawancara terhadap 34 orang penjahit 
didapatkan bahwa penjahit mengalami kelelahan otot mata dan kelelahan saraf mata sebagai akibat tegangan yang secara terus menerus pada mata. Gangguan yang sering terjadi seperti kesalahan saat memasukan benang, objek terlihat ganda, pandangan kabur, mata terasa tegang, mata lelah, mata mengantuk.

Berdasarkan uraian latar belakang diatas maka penulis tertarik untuk melakukan penelitian dengan judul "Hubungan Sikap Kerja, Pencahayaan dan Suhu terhadap kelelahan kerja dan kelelahan mata pada Penjahit di Kampung Solor Kupang 2017".

\section{METODE PENELITIAN}

$\begin{array}{ccr}\text { Jenis } & \text { penelitian } & \text { merupakan } \\ \text { penelitian } & \text { kuantitatif } & \text { dengan }\end{array}$ menggunakan metode penelitian survei analitik dengan pendekatan cross sectional. Penelitian cross sectional adalah suatu penelitian analitik dimana proses pengumpulan atau pengambilan data menyangkut variabel yang diteliti dan variabel yang tidak diteliti akan dikumpulkan dan diukur pada waktu yang bersamaan (Notoatmodjo, 2010).

\section{HASIL DAN PEMBAHASAN}

1. HASIL

a. Gambaran Umum Lokasi Penelitian

Penelitian ini dilakukan pada tanggal 07 Juni - 20 Juni 2017 yang berlokasi di beberapa tempat usaha informal penjahitan pakaian di wilayah Kecamatan Kota Lama Kelurahan Solor Kota Kupang. Jumlah tempat usaha yang di observasi sebanyak enam belas tempat usaha penjahitan, dengan jumlah penjahit yang di wawancara sebanyak 34 orang penjahit.

Setiap tempat usaha penjahitan memiliki pekerja sebanyak 1-4 orang, rata-rata penjahit mampu menyelesaikan 1 sampai 4 potong pakaian per orang per harinya.

\section{b. Gambaran Karakteristik Penjahit}

\section{a. Umur}

Distribusi umur penjahit di tempat usaha penjahitan Kampung Solor Kupang 2017, menunjukkan bahwa dari 34 penjahit yang ada di Kampung Solor Kupang 2017, terbanyak pada penjahit dengan umur 31- 40 yaitu 13 (38,2\%) orang dan yang sedikit adalah penjahit dengan umur 21-30 tahun sebanyak $6(17,6 \%)$ orang.

\section{b. Jenis kelamin}

Distribusi jenis kelamin penjahit di tempat usaha penjahit Kampung Solor Kupang 2017, menunjukkan bahwa dari 34 penjahit yang ada di Kampung Solor Kupang 2017, terbanyak penjahit dengan jenis kelamin laki-laki yaitu $22(64,7 \%)$ orang dan penjahit perampuan 12 $(35,3 \%)$ orang.

\section{c. Masa Kerja}

Distribusi masa kerja penjahit di tempat usaha penjahitan Kampung Solor Kupang 2017, menunjukkan bahwa dari 34 penjahit yang ada di Kampung Solor Kupang 2017, terbanyak dengan masa kerja 1-10 tahun yakni 19 (55,9\%) orang dan penjahit paling sedikit adalah penjahit dengan masa kerja $<1$ tahun yaitu sebesar $3 \quad(8,82 \%)$ orang. 


\section{c. Analisis Univariabel}

\section{Sikap Kerja}

Distribusi hasil pengukuran sikap kerja pada penjahit di Kampung Solor Kupang 2017, menunjukkan bahwa dari total 34 penjahit terdapat $16(47,1 \%)$ orang penjahit dengan tingkat risiko sikap kerja Tinggi dan terdapat sebanyak $2(5,9$ $\%$ ) orang penjahit dengan tingkat resiko sikap Rendah.

\section{Pencahayaan}

Distribusi hasil pengukuran pencahayaan pada tempat jahit di Kampung Solor Kupang 2017, menunjukkan bahwa dari total 16 tempat jahit terdapat $9 \quad(56,2 \%)$ tempat jahit yang intensitas pencahayaannya tidak memenuhi syarat dan $7(43,7 \%)$ tempat jahit yang intensitas pencahayaannya memenuhi syarat.

\section{Suhu}

Distribusi hasil pengukuran suhu pada tempat jahit di Kampung Solor Kupang 2017, menunjukkan bahwa dari total 16 tempat jahit terdapat 13 (81,25\%) tempat jahit yang suhunya tidak memenuhi syarat dan 3 (18,75 \%) tempat jahit yang suhunya memenuhi syarat.

\section{Kelelahan Kerja}

Distribusi hasil pengkuran tingkat kelelahan kerja pada penjahit di Kampung Solor Kupang 2017, menunjukkan bahwa dari total 34 penjahit terdapat sebanyak 18 (52,9 $\%)$ orang penjahit dengan kriteria kelelahan kerja tinggi dan penjahit dengan kriteria kelelahan kerja rendah terdapat sebanyak $1(2,9 \%)$ orang.

\section{Kelelahan Mata}

Distribusi hasil pengukuran tingkat kelelahan mata pada penjahit di Kampung Solor Kupang 2017, menunjukkan bahwa dari total 34 penjahit terdapat sebanyak 13 $(38,2 \%)$ orang penjahit dengan tingkat kelelahan mata tinggi dan penjahit dengan tingkat kelelahan rendah terdapat sebanyak $5(14,7 \%)$ orang.

\section{PEMBAHASAN}

a. Hubungan Sikap kerja dengan Kelelahan Kerja pada Penjahit di Kampung Solor Kupang 2017.

Sikap kerja adalah posisi tubuh pekerja pada saat melakukan pekerjaan. Posisi tubuh dalam kerja sangat ditentukan oleh jenis pekerjaan yang berbeda-beda terhadap tubuh. Masing-masing posisi kerja mempunyai pengaruh yang berbeda-beda (Tarwaka, 2004).

Hasil analisis dengan menggunakan uji Chi Square diperoleh nilai $\mathrm{p}<\alpha(0,05)$, dengan nilai $\mathrm{p}=0,011$ yang berarti ada hubungan antara sikap kerja dengan kelelahan kerja pada penjahit di Kampung Solor Kupang 2017.

Hasil penelitian di penjahit Kampung Solor Kupang menunjukkan bahwa ada hubungan antara sikap kerja dengan kelelahan kerja pada penjahit disebabkan karena lamanya duduk pekerja yang menjahit diatas $>8$ jam/hari bekerja dalam waktu yang lama akan menimbulkan kejenuhan dan kelelahan, postur tubuh yang janggal dan sifat kerja yang monoton (berulang-ulang) dapat menyebabkan keluhan sakit pada 
leher, punggung, bahu, kaki, serta tangan. Karena semakin lama seseorang bekerja semakin lama pula seseorang terpajan risiko untuk mengalami keluhan nyeri otot (Tarwaka, 2010).

Penelitian ini sejalan dengan penelitian yang dilakukan oleh Maria Ulfa (2013) tentang sikap kerja yang berhubungan dengan keluhan subjektif pada penjahit yang menyatakan duduk dalam waktu yang lama akan menimbulkan kejenuhan dan kelelahan.

b. Hubungan Sikap kerja dengan Kelelahan Mata pada Penjahit di Kampung Solor Kupang 2017.

Sikap kerja adalah posisi tubuh pekerja pada saat melakukan pekerjaan. Posisi tubuh dalam kerja sangat ditentukan oleh jenis pekerjaan yang berbeda-beda terhadap tubuh. Masing-masing posisi kerja mempunyai pengaruh yang berbeda-beda (Tarwaka, 2004).

$$
\text { Hasil analisis dengan }
$$

menggunakan uji Chi Square diperoleh nilai $\mathrm{p}>\alpha(0,05)$, dengan nilai $p=0,037$ yang berarti ada hubungan antara sikap kerja dengan kelelahan mata pada penjahit di Kampung Solor Kupang 2017.

Hasil penelitian di penjahit Kampung Solor Kupang menunjukkan bahwa ada hubungan antara sikap kerja dengan kelelahan mata pada penjahit disebabkan karena penjahit yang bekerja pada posisi duduk dan tata letak meja kerja dengan arah cahaya lampu yang tepat di depan mata, tata letak meja kerja yang menghadap ke arah jendela sehingga terjadi kesilauan yang diakibatkan dari cahaya matahari sehingga penjahit mengalami kelelahan mata.
Penelitian ini sejalan dengan penelitian yang dilakukan oleh Santoso (2011) tentang hubungan pencahayaan dan karakteristik pekerja dengan kelelahan subyektif pada operator komputer yang menyatakan bahwa terdapat kecendrungan hubungan kelelahan mata karena bayangan dan kesilauan yang diakibatkan dari salah penempatan stasiun kerja.

\section{c. Hubungan Pencahayaan dengan Kelelahan Kerja pada Penjahit di Kampung Solor Kupang 2017}

Intensitas pencahayaan adalah banyaknya cahaya yang tiba pada satu luas permukaan (Achmadi, 1990). Pencahayaan yang baik adalah pencahayaan yang memungkinkan tenaga kerja dapat melihat objekobjek yang dikerjakan secara jelas, cepat dan tanpa upaya-upaya yang tidak perlu (Suma'mur, 2009).

Menurut Budiono (2003) akibat penerangan yang buruk dapat menyebabkan kelelahan mata dengan berkurangnya daya dan efisiensi kerja, kelelahan mental, keluhan-keluhan pegal didaerah mata, sakit kepala sekitar mata, merusakan alat penglihatan serta meningkatnya kecelakaan.

Hasil analisis dengan menggunakan uji Chi Square diperoleh nilai $p>\alpha(0,05)$, dengan nilai $\mathrm{p}=0,683$ yang berarti tidak ada hubungan antara pencahayaan dengan kelelahan pada penjahit di Kampung Solor Kupang 2017.

Hasil penelitian di penjahit Kampung Solor Kupang menunjukkan bahwa tidak ada hubungan intensitas pencahayaan dengan kelelahan kerja disebabkan karena penjahit lebih merasakan kelelahan pada bagian mata apabila 
dibandingkan dengan kelelahan yang bersifat subyektif. Hal ini karena intensitas pencahayaan di tiap tempat jahit berbeda-beda yang digunakan oleh penjahit. Penjahit dengan intensitas pencahayaan tidak memenuhi syarat lebih memaksa kemampuan akomodasi mata untuk melihat obyek yang digunakan sehingga terjadi stres pada organ mata dan menyebabkan kelelahan mata.

Hasil penelitian ini sejalan dengan penelitian yang dilakukan oleh Firmansyah (2010) tentang pengaruh intensitas penerangan terhadap kelelahan mata yang mengatakan bahwa intensitas penerangan yang kurang baik dapat mempengaruhi kelelahan mata.

\section{d. Hubungan Pencahayaan dengan Kelelahan Mata pada Penjahit di Kampung Solor Kupang 2017}

Intensitas pencahayaan adalah banyaknya cahaya yang tiba pada satu luas permukaan (Achmadi, 1990). Pencahayaan yang baik adalah pencahayaan yang memungkinkan tenaga kerja dapat melihat objekobjek yang dikerjakan secara jelas, cepat dan tanpa upaya-upaya yang tidak perlu (Suma'mur, 2009).

Menurut Budiono (2003) akibat penerangan yang buruk dapat menyebabkan kelelahan mata dengan berkurangnya daya dan efisiensi kerja, kelelahan mental, keluhan-keluhan pegal didaerah mata, sakit kepala sekitar mata, merusakan alat penglihatan serta meningkatnya kecelakaan.

$$
\text { Hasil analisis dengan }
$$

menggunakan uji Chi Square diperoleh nilai $\mathrm{p}<\alpha(0,05)$, dengan nilai $\mathrm{p}=0,045$ yang berarti ada hubungan antara pencahayaan dengan kelelahan mata pada penjahit di Kampung Solor Kupang 2017.

Hasil penelitian di Kampung Solor Kupang menunjukkan bahwa adanya hubungan intensitas pencahayaan dengan kelelahan mata disebabkan kurangnya penggunaan lampu di setiap tempat jahit, sehingga cahaya lampu tidak menyebar secara merata. Penerangan yang buruk akan mengakibatkan rendahnya produktivitas juga kualitas maupun sakit mata, lelah dan pening kepala bagi pekerja. Penerangan yang lebih baik dapat memberikan hal berupa efisiensi yang lebih tinggi, dapat meningkatkan produktivitas dan mengurangi kesulitan serta tekanan penglihatan terhadap pekerjaan (Budiono, 1991).

Hasil penelitian ini sejalan dengan yang dilakukan oleh Riski (2006) tentang hubungan antara intensitas penerangan dan suhu udara dengan kelelahan mata karyawan pada bagian administrasi yang menyatakan bahwa intensitas pencahayaan yang kurang disebabkan distribusi cahaya yang kurang merata menyebabkan mata dipaksa untuk menyesuaikan bermacam-macam kontras kilau sehingga kelelahan mata akan lebih cepat terjadi.

Selain itu penjahit yang bekerja pada posisi duduk dan tata letak meja kerja dengan arah cahaya lampu yang tepat di depan mata, tata letak meja kerja yang menghadap ke arah jendela sehingga terjadi kesilauan yang diakibatkan dari cahaya matahari sehingga penjahit mengalami kelelahan mata.

Penelitian ini sejalan dengan penelitian yang dilakukan oleh Santoso (2011) tentang hubungan 
pencahayaan dan karakteristik pekerja dengan kelelahan subyektif pada operator komputer yang menyatakan bahwa terdapat kecendrungan hubungan kelelahan mata karena bayangan dan kesilauan yang diakibatkan dari salah penempatan stasiun kerja.

e. Hubungan Suhu dengan Kelelahan Kerja pada Penjahit di Kampung Solor Kupang 2017

Suhu dingin mengurangi efisiensi dengan keluhan kaku atau kurangnya koordinasi otot. Suhu panas terutama berakibat menurunnya prestasi kerja pikir. Penurunan sangat hebat sesudah 32 ${ }^{\circ} \mathrm{C}$. Suhu panas mengurangi kelincahan, memperpanjang waktu reaksi dan waktu pengambilan keputusan, mengganggu kecermatan kerja otak, mengganggu koordinasi syaraf perasa dan motoris (Suma'mur, 1996). Persyaratan kesehatan untuk ruang kerja industri yang nyaman ditempat kerja adalah suhu yang tidak dingin dan tidak menimbulkan kepanasan bagi tenaga kerja. Menurut Keputusan Menteri Kesehatan Republik Indonesia Nomor 1405 tahun 2002 suhu lingkungan kerja yang nyaman adalah berkisar $18-30{ }^{\circ} \mathrm{C}$ dengan tinggi langit-langit dari lantai minimal $2,5 \mathrm{~m}$.

Hasil analisis dengan

menggunakan uji Chi Square diperoleh nilai $\mathrm{p}<\alpha(0,05)$, dengan nilai $\mathrm{p}=0,023$ yang berarti ada hubungan antara suhu dengan kelelahan pada penjahit di Kampung Solor Kupang 2017.

Hasil penelitian di penjahit Kampung Solor Kupang menunjukkan bahwa ada hubungan antara suhu dengan kelelahan kerja pada penjahit disebabkan karena Pada tempat kerja dengan suhu ruangan yang panas maka akan menyebabkan proses pemerasan keringat. Beberapa hal buruk berkaitan dengan kondisi demikian dapat dialami oleh tenaga kerja, salah satunya kelelahan kerja. Pekerja yang mengalami kondisi demikian, sulit untuk mampu bereproduksi tinggi. Akibat kelelahan kerja tersebut, para pekerja menjadi kurang bergairah kerja, daya tanggap dan rasa bertanggung jawab menjadi rendah, sehingga seringkali kurang memperhatikan kualitas produk kerjanya.

Penelitian ini sejalan dengan penelitian yang dilakukan oleh Paulina \& Salbiah (2016) tentang faktor-faktor yang berhubungan dengan kelelahan pada pekerja di PT Kalimantan Steel yang menyatakan bahwa ada hubungan antara suhu dengan kelelahan pekerja disebabkan suhu lingkungan tempat kerja yang tinggi.

f. Hubungan Suhu dengan Kelelahan Mata pada Penjahit di Kampung Solor Kupang 2017.

Suhu dingin mengurangi efisiensi dengan keluhan kaku atau kurangnya koordinasi otot. Suhu panas terutama berakibat menurunnya prestasi kerja pikir. Penurunan sangat hebat sesudah 32 ${ }^{\circ} \mathrm{C}$. Suhu panas mengurangi kelincahan, memperpanjang waktu reaksi dan waktu pengambilan keputusan, mengganggu kecermatan kerja otak, mengganggu koordinasi syaraf perasa dan motoris (Suma'mur, 1996). Persyaratan kesehatan untuk ruang kerja industri yang nyaman ditempat kerja adalah suhu yang tidak dingin dan tidak 
menimbulkan kepanasan bagi tenaga kerja. Menurut Keputusan Menteri Kesehatan Republik Indonesia Nomor 1405 tahun 2002 suhu lingkungan kerja yang nyaman adalah berkisar $18-30{ }^{\circ} \mathrm{C}$ dengan tinggi langit-langit dari lantai minimal $2,5 \mathrm{~m}$.

Hasil analisis dengan menggunakan uji Chi Square diperoleh nilai $\mathrm{p}>\alpha(0,05)$, dengan nilai $\mathrm{p}=0,106$ yang berarti tidak ada hubungan antara suhu dengan kelelahan mata pada penjahit di Kampung Solor Kupang 2017.

Hasil penelitian di penjahit Kampung Solor Kupang menunjukkan bahwa tidak ada hubungan antara suhu dengan kelelahan mata pada penjahit, jika suhu lingkungan tempat kerja yang tinggi dapat menyebabkan proses pengurasan keringat, dengan kondisi demikian dapat dialami oleh tenaga kerja, salah satunya kelelahan kerja. Akibat kelelahan kerja tersebut, para pekerja menjadi kurang bergairah kerja, daya tanggap dan rasa tanggung jawab menjadi rendah. Suhu dapat mempengaruhi prestasi kerja pikir, mengurangi kelincahan, mengganggu kecermatan otak, mengganggu syaraf perasa dan motoris dibandingkan dengan kelelahan mata, mata lelah jika intensitas penerangan kurang dan mengamati objek yang berukuran kecil dalam waktu lama. Menurut Siswanto(1993), kelelahan mata timbul akibat stres pada otot-otot akomodasi yaitu saat seseorang mengamati subyek berukuran kecil pada jarak dekat, serta dalam waktu yang lama. Dalam kondisi penerangan yang buruk, mata berusaha untuk lebih dekat pada obyek yang diamati. Hal ini dilakukan dengan meningkatkan usaha akomodasi mata yaitu upaya untuk menambah daya bias lensa dengan kontras otot-otot siliar, menyebabkan penambahan tebal dan kecembungan lensa sehingga bayangan benda pada jarak yang berbeda-beda akan terfokus di retina. Pada kondisi demikian otot-otot mata akan bekerja secra terus menerus dan lebih dipaksakan ketegangan pada otot akomodasi atau otot siliar makin besar sehingga terjadi kelelahan mata.

Penelitian ini sejalan dengan penelitian yang dilakukan oleh Andri (2012) tentang analisis tingkat pencahayaan dan keluhan kelelahan mata pada pekerja di area produksi pelumas yang menyatakan bahwa intensitas pencahayaan yang kurang memadai membuat mata pekerja bekerja lebih keras untuk dapat melihat suatu objek sehingga dapat memicu terjadinya kelelahan mata pada pekerja.

\section{SIMPULAN DAN SARAN Simpulan}

Simpulan yang didapat dari hasil penelitian hubungan sikap kerja, pencahayaan, dan suhu terhadap kelelahan kerja dan kelelahan mata pada penjahit di Kampung Solor Kupang 2017 adalah sebagai berikut:

1. Ada hubungan antara sikap kerja dengan kelelahan kerja pada penjahit di Kampung Solor Kupang 2017, dengan nilai $\mathrm{p}=0,011$.

2. Ada hubungan antara sikap kerja dengan kelelahan mata pada penjahit di Kampung Solor Kupang 2017, dengan nilai $\mathrm{p}=0,037$.

3. Tidak ada hubungan antara pencahayaan dengan kelelahan kerja 
pada penjahit di Kampung Solor Kupang 2017, dengan nilai $\mathrm{p}=0,683$.

4. Ada hubungan antara pencahayaan dengan kelelahan mata pada penjahit di Kampung Solor Kupang 2017, dengan nilai $\mathrm{p}=0,045$.

5. Ada hubungan antara suhu dengan kelelahan kerja pada penjahit di Kampung Solor Kupang 2017, dengan nilai $\mathrm{p}=0,023$.

6. Tidak ada hubungan antara suhu dengan kelelahan mata pada penjahit di Kampung Solor Kupang 2017, dengan nilai $\mathrm{p}=0,106$

\section{Saran}

1. Bagi pengelola usaha

a. Dilakukan penambahan baik dari segi kualitas maupun kuantitas lampu sebagai sumber pencahayaan untuk mengatasi intensitas pencahayaan yang tidak memenuhi syarat. Seperti penambahan jumlah lampu yang digunakan yang diletakan pada tiap titik dimana penjahit melakukan kegiatan menjahit serta penambahan terang cahaya pada lampu yang digunakan, pemakaian lampu pada tiap meja kerja sebagai pencahayaan lokal.

b. Pengaturan waktu istirahat untuk penjahit, setelah bekerja selama 4 jam diberikan waktu istirahat selama 30 menit, setelah 2 jam kemudian berikan istirahat 15 menit, dan setelah 2 jam berikut berikan lagi istirahat 15 menit.

c. Posisi kerja jika menghadap ke arah matahari di pasang dengan tirai, pada saat pencahayaan yang menyilaukan di tutup tirainya.

d. Pengaturan ruangan kerja ditata lebih baik lagi sehingga ruangan tidak terlihat penuh sehingga udara bisa masuk dan jika udara terlalu panas gunakan kipas angin sehingga tidak mengganggu kecermatan otak.

2. Bagi peneliti lain

Penelitian tentang hubungan sikap kerja, pencahayan dan suhu terhadap kelelahan kerja dan kelelahan mata pada penjahit masih jauh dari sempurna. Adapun saran untuk penelitian selanjutnya untuk melengkapi penelitian ini diantaranya:

a. Pengukuran dan pemeriksaan untuk mengetahui hubungan kelelahan kerja terhadap variabel lain seperti beban kerja, kelembaban.

b. Penggunaan metode lain dalam pengukuran sikap kerja selain metode RULA (Metode REBA, BRIEF,OWAS).

\section{DAFTAR RUJUKAN}

[1] Achmadi, U. F.1990.Upaya Kesehatan Kerja Sektor Informal di Indonesia. Jakarta : Depkes RI.

[2] Agnestry,P.S.,Kalsum, \& M.M.Sinaga. 2015. Hubungan Sikap Kerja Dengan Musculoskeletal Disorders Pada Penjahit Di Pusat Industri Kecil Menteng Medan. Skripsi: Fakultas Kesehatan Masyarkat, Universitas Sumatera Utara.

[3] Anizar. (2012). Teknik Keselamatan dan Kesehatan Kerja Industri Cetakan Ke-2 . Jakarta: Graha Ilmu.

[4] Ariyanti, R.C.2016. Hubungan Antara Intensitas Penerangan Dan Suhu Udara Dengan Kelelahan Mata Karyawan Pada Bagian Administrasi Di PT. Hutama Karya Wilayah IV Semarang. Skripsi: Jurusan Ilmu Kesehatan Masyarakat, Fakultas :Ilmu 
Keolahragaan, Universitas Negeri Semarang.

[5] Budiono. (2003). Kelelahan (Fatigue) pada Tenaga Kerja. Bunga Rampai Hiperkes dan Keselamatan Kerja Edisi ke-2. Semarang: Universitas Diponegoro.

[6] Depkes RI. (2003). Modul Pelatihan Bagi Fasilitator Kesehatan Kerja. Jakarta: Depkes RI Pusat Kesehatan Kerja.

[7] Depkes RI. (2002). Persyaratan Kesehatan Lingkungan Kerja Perkantoran dan Industri. Jakarta. Keputusan Menteri Kesehatan Republik Indonesia Nomor 1405/MENKES/SK/XI/2002.

[8] Firmansyah, F.2010. Pengaruh Intensitas Penerangan Terhadap Kelelahan Mata eprints.uns.ac.id/122/1/167100309 201010441.pdf (Diakses pada tanggal 25 Agustus 2017).

[9] Gempur, S. (2003). Manajemen Keselamatan dan Kesehatan Kerja . Jakarta: Prestasi Pustaka.

[10] Gempur, S. (2004). Manusia, Peralatan dan Lingkungan. Jakarta: Prestasi Pustaka.

[11] Guyton. (1991). Fisiologi Kedokteran II, Diterjemahkan oleh Adji Dharma. Jakarta: EGC Buku Kedokteran.

[12] Harrianto, R. (2010). Buku Ajar Kesehatan Kerja . Jakarta: Buku Kedokteran EGC.

[13] Indriati, T. (2015). Hubungan Intensitas Pencahayaan, Suhu, dan Beban Kerja Dengan Kelelahan Kerja Penjahit Di Pasar Kampung Solor Kota Kupang. Kupang: Fakultas Kesehatan Masyarakat Universitas Nusa Cendana.

[14] Nina.W \& Tri M.2004. Hubungan Intensitas Penerangan dengan Kelelahan Mata Pada Pengrajin Batik Tulis. Skripsi: Fakultas
Kesehatan Masyarakat ,Universitas Airlangga

[15] Notoatmodjo, S. (2003). Pendidikan dan Perilaku Kesehatan. Jakarta: Rineka Cipta.

[16] Notoatmodjo, S. (2010). Metodologi Penelitian Kesehatan. Jakarta: Rineka Cipta.

[17] Nurmianto, E. (2003). Ergonomi Konsep Dasar dan Aplikasinya. Tinjau Ergonomi, Psikologi, dan Kompetensi untuk Perancangan Kerja dan Produk. Surabaya: Guna Widya.

[18] Paulina \& Salbiah.2016.Faktorfaktor yang Berhubungan Dengan Kelelahan Pada Pekerja Di PT Kalimantan Steel. Skripsi : Jurusan Kesehatan Lingkungan, Poltekkes Kemenkes Pontianak.

[19] Rai, P. C. (2006). Pengaruh Penerangan Dalam Ruang Terhadap Produktivitas Mahasiswa Desain Interior. http://www.petra.ac.id/ᄀpuslit/jo urnals/dir.php?DepartemenID=IN T. Diakses pada tanggal 7 januari 2017.

[20] Ramadhani, A.F. 2012. Analisis Tingkat Pencahayaan Dan Keluhan Kelelahan Mata Pada Pekerja Di Area Produksi Pelumas Jakarta PT Pertamina (Persero) Tahun 2002. Skripsi : Fakultas Kesehatan Mayarakat, Program Sarjana Kesehatan Mayarakat Keselamatan Dan Kesehatan Kerja Depok.

[21] Rosy.D.2011.Hubungan Tekanan Panas dengan Kelelahan Kerja. eprints.uns.ac.id/8515/1/2174308 11201104371.pdf (diakses 25 Agustus 2017).

[22] Sedarmayanti. (2009). Tata Kerja dan Produktivitas Kerja. Bandung: Mandar Maju.

[23] Sihombing, A. P. (2015). Hubungan Sikap Kerja Dengan Muscoluskeletal 
Disorders Pada Penjahit Di Pusat Industri Kecil Menteng Medan 2015.

Medan: Fakultas Kesehatan Masyarakat Universitas Sumatera Utara.

[24] Siswanto. (1993). Penerangan. Jakarta: Balai Pelayanan Ergonomi KesKer.

[25] Siswatiningsih.1998. Hubungan Antara Intensitas Penerangan dengan Kelelahan. eprints.undip.ac.id/8804/(25 Agustus 2017).

[26] Soewarno. (1992). Penerangan Tempat Kerja. Jakarta: Pusat Pelayanan Ergonomi dan Kesker.

[27] Suma'mur. (1989). Ergonomi untuk Produktivitas Kerja. Jakarta: CV Haji Masagung.

[29] Suma'mur. (1996). Higiene Perusahaan dan Keselamatan Kerja. Jakarta: PT. Toko Gunung Agung.

[30] Suma'mur. (2009). Higene Perusahaan dan Kesehatan Kerja. Jakarta: Sagung Seto.

[31] Sunyoto. (2011). Analisis Data Untuk Penelitian Dengan SPSS Untuk Mahasiswa dan Praktisi Kesehatan. Yogyakarta. Nuha Medika.
[32] Syamruth, Y. (2009). Buku Ajar Biostatistika Inferensial (Aplikasi dalam ilmu-ilmu kesehatan). Kupang: Undana Press.

[33] Tarwaka, Bakri. S,HA dan Sudiajeng.L. (2004). Ergonomi untuk Kesehatan, Keselamatan Kerja, dan Produktivitas. Edisi Ke-1 . Surakarta: UNIBA Press.

[34] Tarwaka. (2013). Ergonomi Industri, Dasar-dasar Pengetahuan dan Aplikasi di Tempat Kerja. Edisi Ke-1. Surakarta: Harapan Press.

[35] Tunggul \& Koesyanto. (2005). Panduan Praktikum Laboratorium Kesehatan dan Keselamatan Kerja . Semarang: UPT UNNES Press.

[36] Ulfa, M.,\& Indriati. 2013. Sikap Kerja yang Berhubungan Dengan Keluhan Subjektif Pada Penjahit Di Jalan Patua Surabaya. Skripsi: Fakultas Kesehatan Masyarakat, Universitas Airlanggga.Surabaya.

[37] Umiyati.2009. Faktor-faktor Yang Berhubungan Dengan Kelelahan Kerja Pada Penjahit.repository.uinjkt.ac.id/dsp ace/bitstream/.../1/92637UMIYATI-FKIK.pdf (25 Agustus 2017). 